\title{
THE STUDENTS' PERSPECTIVES ON OBSERVING LANGUAGE USE IN SOCIAL MEDIA AS SOCIAL PRACTICE
}

\author{
Arina Isti'anah \\ E-mail: arina@usd.ac.id \\ Sanata Dharma University \\ Yogyakarta, Indonesia
}

\begin{abstract}
In this digital era, college students have become familiar with social media such as Facebook, twitter, and Instagram. For English Letters Students, they also use English when updating their status, tweeting their thought, or giving captions in their photos. That phenomenon results in the students' interest in analyzing language use in social media, proven by some theses examining social media as the data. It means that the students have started to observe English language and literacy as social practice, for example is when a student observed English Letters students' grammatical errors in their social media accounts. That fact reveals the student's awareness of the importance of English language and literacy as social practice. A questionnaire was distributed to 64 students who take Language Research Methodology Class. Most of them access Instagram and Facebook in their daily life and spend half of their day accessing the media. Their activities involve reading posts on information and observe comments in the form of sentences. Pedagogical implication of the students' responses was teachers should bring social issues which happen in society in which the students live to build their critical thinking. Therefore, the students are involved in social practice while developing their critical literacy.
\end{abstract}

Key words: social media, language, literacy, social practice

\section{INTRODUCTION}

As a foreign language in Indonesia, English is not only used in school as one of the compulsory subjects for the students, but also a medium for self-expression. In this global world, social networking involving social media have been used by teachers to motivate students improve their language and literacy. Social media encompasses a wide variety of internet networking and communication tool which the students can have resource in nearly every aspect of their life (Faizi, 
Afia, \& Chibeb). Social media provide enormous opportunities for the students to practice their language and literacy while connecting to people around the world. When social media are used for teaching learning activity, the students can share knowledge through peer-review activities and connect themselves internationally through language exchange (Brick, 2012, p. 35).

To use English in social media, students actually experience a social process in which language learners/users actively participate, perform particular social roles and arrange their situated identities (Chen, 2013, p. 143). To negotiate their situated identities, learners actually present themselves in two ways: through the construction of profiles and interactions with social network users (Buck, 2012, p. 15). The first way is presented by the status updates or posts they make, while the second way is observed from how they respond language used by other people. In Indonesian context, to use English in those two ways, the students are in the process of second language learning.

Second language learning is performed by conscious knowledge of a second language on which the students know the rules, be aware of the rules, and be able to talk about them (Krashen, 2009). In second language learning, the language learner is "presented not only as someone in the process of learning but also, by implications, as someone who intends to learn and, a further implication, who is somehow controlling at least part of the activity we call learning" (Smith, 1995, p. 12). In this stage, the students do not only learn how to use language in social media in their updates, but also start to be aware of the language use they choose and observe. In relation to the previous notion, the students of English Letters Department, Sanata Dharma University, are expected to criticize the language use in social media and figure out what language phenomenon happens in the choice of language use.

Observing language use in social media means that the students are involved in social practice. Social practice, in the view of sociocultural theory, believes that learning is socially constructed in and through interaction in situated activities (Kurata, 2011, p. 10). The theory is also interested in the relationship between individuals and their social worlds (Kurata, 2011, p. 11). Therefore, it is important to figure out how the students put themselves in the storm of social media life. 
The questions on whether they can improve their language and literacy and whether they are able to figure out language phenomena in social media have become delicate enquires to research.

Social practice theory is interested in the fact that literacy practices are embedded in broader social and cultural practices and are influenced by the context in which it happens (Gerger, 2014, p. 86). In social media context, the students are faced by interactive processes that enable language to become a cognitive tool for learner by which the second language changes from being unfamiliar towards utilizing second language as the interactive and cognitive resource for themselves (Kurata, 2011, p. 11). The previous process is called internalization.

Language as social practice perspectives show how language learners observe and enter into communication online, how it augments their non-digital exchanges, and how such practices may or may not assist learners in achieving their larger social purposes. Thus, the students are motivated to recognize, identify, and address linguistic barriers to participation (Barton \& Potts, 2013, p. 817).

Students' perceptions on social media use in language learning was conducted by Faizi et al. The research found that most of the participants involved in the survey stated that social networking sites are used to improve their language and communication skills or even to learn new languages. Brick (2012) also conducted a similar research in UK higher education. Social networking sites are welcome by both students and teachers in UK higher education since the sites are used as tools to reward the students in the form of points. Dovchin (2015) observed translingual by youth learners in Facebook. The research found that "translingual practices of modern youth learners provide a significant insight into the co-existence of multiple authenticities and origins of authenticity in an increasingly interconnected world" (Dovchin, 2015, p. 437).

The previous studies above concern the development of students' literacy in learning second language. Literacy itself is divided into three major categories: functional, critical, and liberal. Functional literacy is required for both society's demands and individual needs and purposes (Papen, 2005, p. 9). Critical literacy, as described by Freire and Macedo (1987) refers to the potential of literacy as not only reading 
"the word", but also reading "the world", which language learners are invited to understand the world in terms of justice and injustice(Papen, 2005 , p. 10). On the other hand, liberal literacy regards literacy education as a welfare activity to emphasize personal development and individual goals (Papen, 2005, p. 11).

Motivated by the previous paragraphs, this paper attempts at figuring out the students' process in accessing social media. The first motivation is to find out whether or not the students have been in the internalization process and whether they have developed critical literacy while accessing the social media. To answer the previous enquiry, a questionnaire about the students' activities when accessing social media was designed by developing Ellison's points of view on social network sites which allow individuals to "construct a public or semi-public profile within bounded system, articulate a list of other users with whom they share a connection, and view and traverse their list of connections and those made by others within the system” (Buck, 2012, p. 11).

\section{METHOD}

This paper conducted a descriptive quantitative research since it describes the percentage to understand the patterns for understanding any other analysis that follows (Brown, 2011, p. 192). A questionnaire was distributed to the sixth semester students taking Language Research Methodology class. Questionnaire was chosen as the instrument to gather the data because it allows the researcher to gather information that learners are able to report about themselves, including their beliefs and motivation about learning or their reactions to learning and classroom activities (Mackey \& Gass, 2005). The questionnaire was divided into two parts: the first part is to find out the information related to social media the students access and the frequency accessing the social media, while the second part is in a closed-item which provides options related to students' perspectives about their experience when accessing the social media. Closed-item was chosen as it provides a greater uniformity of measurement and greater reliability (Mackey \& Gass, 2005). However, the last option in the closed-item is in the form of alternative answer to anticipate students' experience 
which is not provided in the option. Therefore, truthful answer is expected to achieve.

There were 64 participants from the sixth semester of English Letters Department, Sanata Dharma University. The participants' background was they have taken courses on linguistics: phonetics, phonology, morphology, sociolinguistics, semantics, and syntax. The previous courses are expected to give the students' background knowledge when they observe language use in social media. This research conducted a convenience sampling as the members of the study are selected based on the criteria the researcher chose. However, it is also purposive since, besides the relative ease of accessibility, participants have to possess certain key characteristics that are related to the purpose of investigation (Dornyei, 2003, p. 72).

\section{DISCUSSION}

Comprehending the students' context becomes an inseparable part when discussing their perspectives on language use in social media. As involved in the social practice in this digital era, the students are assigned to mention the social media they use and the average frequency of accessing the media in a day. After describing the context, the students' experience when accessing social media is described in the next part. The results of the questionnaire reflect the students' process as engaged in social practice. This paper also presents some pedagogical implications based on the students' experience as reflected in the questionnaire.

\section{The Context of Students}

The first context observed from the students is the kinds of social media they access. The questionnaire provide three social media in the closed items: Facebook, Instagram and Twitter. To accommodate the students' answers, the last option is in the form of alternative answer which the students can write other social media accounts they do not choose in the closed items. The table below displays the summary of the students' context involving the social media they use and the frequency they access the media. 
Table 1. Students' Social Media and their access frequency

\begin{tabular}{|l|c|c|}
\hline \multicolumn{1}{|c|}{ Social Media } & $\begin{array}{c}\text { Number of } \\
\text { Students }\end{array}$ & Percentage \\
\hline Facebook & 51 & $79.68 \%$ \\
\hline Instagram & 54 & $84.34 \%$ \\
\hline Twitter & 36 & $56.25 \%$ \\
\hline Line & 38 & $59.34 \%$ \\
\hline WhatsApp & 34 & $53.12 \%$ \\
\hline BlackBerry Messenger & 16 & $25 \%$ \\
\hline Path & 17 & $26.56 \%$ \\
\hline YouTube & 20 & $31.25 \%$ \\
\hline Other accounts & 10 & $15.63 \%$ \\
\hline
\end{tabular}

From the information gathered though the questionnaire, it was found out that Instagram is the most popular social media the students familiar with. Among the participants, Instagram is accessed by 54 students, or $84.34 \%$. The second social media popular among the students is Facebook, accessed by 51 students, or $79.68 \%$. Twitter, Line, and WhatsApp are the following popular social media accounts which are used by more than $50 \%$ of all participants.

The finding reveals that pictures uploaded in Instagram are kinds of updates which attract the participant the most. Instagram users can give caption in the pictures. People can also comment the pictures. Language use in the comments is also delicate to observe. Students can observe how people complement or criticize the pictures. The use of slang words is also often found in the internet use. From Facebook, students can observe how language is used to show solidarity. Facebook users are involved in their virtual world which identity ca be evolved, either consciously or unconsciously (Crystal, 2003, p. 60).

The second part of the questionnaire on the students' context is the average time they spend accessing social media in a day. The table below shows the students' responses. 
Table 2. Students' Average Time in using Social Media

\begin{tabular}{|l|c|c|}
\hline \multicolumn{1}{|c|}{$\begin{array}{c}\text { Average frequency } \\
\text { in a day }\end{array}$} & $\begin{array}{c}\text { Number of } \\
\text { Students }\end{array}$ & Percentage \\
\hline 4 hours & 19 & $29.68 \%$ \\
\hline 6 hours & 15 & $23.43 \%$ \\
\hline 12 hours & 20 & $31.25 \%$ \\
\hline More than 12 hours & 2 & $3.12 \%$ \\
\hline Less than 2 hours & 8 & $12.5 \%$ \\
\hline
\end{tabular}

The table above obviously shows that most of the students, 20 students, spend a half of their day accessing social media, shown in $31.25 \%$. There are 19 students who spend 4 hours a day accessing social media, 15 students spend 6 hours a day, 2 students spend more than 18 hours a day, and 8 students who spend less than 2 hours a day. The finding reveals that most of the students spend half of their day accessing social media. This fact supports the notion that students are categorized as digital natives who are born in the digital era. Thus, they are also called as the iGeneration (Benini \& Murray, 2013, p. 26). The existence of social media has become an integral part of their life. Digital natives have grown up with computers, smart phones, video games, and the internet use effectively as they are natural parts of their lives (Basak \& Yesilel, 2016, p. 98).

\section{The Students' Responses on Language Use in Social Media}

The second part of the questionnaire contains of four questions. The first question is on the students' activity when they access social media. The possible activities are provided in the closed-items: reading posts, posting updates, and observing others' posts. The last option is welcome to fill by the students. The students' responses are displayed below.

Table 3. Students' activity in using social media

\begin{tabular}{|l|c|c|}
\hline $\begin{array}{c}\text { Students' activity when } \\
\text { accessing social media }\end{array}$ & $\begin{array}{c}\text { Number of } \\
\text { Students }\end{array}$ & Percentage \\
\hline Reading posts & 36 & $56.25 \%$ \\
\hline Posting updates & 6 & $9.34 \%$ \\
\hline
\end{tabular}




\begin{tabular}{|l|c|c|}
\hline Observing others' posts & 18 & $28.13 \%$ \\
\hline Other activities & 4 & $6.25 \%$ \\
\hline
\end{tabular}

Among the 64 participants, 36 students or $56.25 \%$ read posts in social media. Another activity dominating the responses is the students' observing posts, represented by 18 students or $28.13 \%$. The next activity done by the 6 students is posting updates, while the other 4 students prefer chatting.

From the questionnaire, the majority of students are involved in social media passively. They just read posts made by other accounts. The 6 students who post updates are in the stage of building their profiles in social media as one of the markers in social practice in social networking sites. The previous stage is also experienced by the 4 students who chose another activity, chatting. By chatting the students build interaction in the virtual world as a marker of social practice. The 18 students who observe others' posts start to develop their critical literacy. This process is followed up in the next part of the questionnaire.

The next question in the questionnaire is on language unit the students observe. The language units provided in the options are phrases, sentences, and conversation. There are no students who observe other language units in social media. Below are the students' responses.

Table 4. Language unit that the students observed

\begin{tabular}{|l|c|c|}
\hline $\begin{array}{c}\text { Language unit the } \\
\text { students observe }\end{array}$ & $\begin{array}{c}\text { Number of } \\
\text { Students }\end{array}$ & Percentage \\
\hline Phrases & 13 & $20.31 \%$ \\
\hline Sentences & 42 & $65.63 \%$ \\
\hline Conversations & 9 & $14.06 \%$ \\
\hline Other units & & \\
\hline
\end{tabular}

From the questionnaire, there are 42 students or $65.63 \%$ of the total participants observe the use of sentences in social media. There are 13 students observephrases and 9 students observe conversation. In Facebook, sentences can be observed from status updates and status comments, while in Instagram are observed in the form of comments. 
This is in line with the last part of the questionnaire asking about language use seen in the social media.

When students are engaged in comment activities, they are involved in conversation activities virtually. Comment activities are categorized in conversation as people give ideas directly in a reply to another idea given by others. Comment activities can be said to be in a synchronous setting as the online members of the group see their contributions appear on the screen soon after they make them all and hope for a prompt response (Crystal, 2003, p. 130).

The third question is on the function of language observed in social media. The provided options in the questionnaire are language is used to share information, persuade others and show identity. Below are the students' responses.

Table 5. Students' purpose in using social media

\begin{tabular}{|l|c|c|}
\hline \multicolumn{1}{|c|}{$\begin{array}{c}\text { Function of language } \\
\text { observed in social media }\end{array}$} & $\begin{array}{c}\text { Number of } \\
\text { Students }\end{array}$ & Percentage \\
\hline To share information & 37 & $57.81 \%$ \\
\hline To persuade others & 7 & $10.94 \%$ \\
\hline To show identity & 17 & $16.56 \%$ \\
\hline Other functions & 3 & $4.69 \%$ \\
\hline
\end{tabular}

Most of the students observe language use in social media as a tool to share information. There are 37 students choose the option. The language to persuade others is recognized by 7 students only, or presented in $10.94 \%$. There are only 17 students who regard language as a means to show identity, realized in $16.56 \%$. Other functions which are written in the last option involve showing habit, feeling and perspective which were chosen by 3 students.

From the previous finding, critical literacy was shown by a half of the participants. Those who develop this kind of literacy do not longer see language as a medium of communication only, but see it as a tool of purpose. There are two purposes offered in the questionnaire: to persuade others and to show identity. In those options, the students start to "read the world". The power of language represented in social media can be exercised by its users to show their purpose. 
The last question is about language use which attracts the students' intention. The questionnaire provides options as shown in the table below.

Table 6. The language use which attracts students' attention

\begin{tabular}{|l|c|c|}
\hline \multicolumn{1}{|c|}{$\begin{array}{c}\text { Language use which attracts } \\
\text { the students }\end{array}$} & $\begin{array}{c}\text { Number of } \\
\text { Students }\end{array}$ & Percentage \\
\hline $\begin{array}{l}\text { How certain group posts } \\
\text { information }\end{array}$ & 22 & $34.34 \%$ \\
\hline $\begin{array}{l}\text { How people comment certain } \\
\text { issue }\end{array}$ & 29 & $45.31 \%$ \\
\hline $\begin{array}{l}\text { How certain language patterns are } \\
\text { used in a group }\end{array}$ & 11 & $17.18 \%$ \\
\hline Other language use & 2 & $3.12 \%$ \\
\hline
\end{tabular}

Most of the students are interested in how people comment on certain issue, represented by 29 students or $43.31 \%$. The following language use is how certain group posts information, chosen by 22 students or $34.34 \%$ among all participants. There are only 11 students interested in how certain language patterns are used in a group. The other language use which involve wrong grammar and contain jokes attract 2 students only.

Responding to the students' choice in the questionnaire, they actually need to be able to bring their critical literacy skills to decoding and analysis of the texts produced across many genres (Morrel, 2013, p. 301). The questionnaire already presented that a half of the participants have started to build their critical literacy. Literacy is a part of participation in social practices in which it involves a combination of doing things, making meanings, relating to others, enacting certain kinds of social identities, and developing certain ways of thinking. (Jones, 2013, p. 844).

\section{Pedagogical Implications of the Students' Responses}

From the findings above, not all participants have developed their critical literacy while accessing social media. To have critical literacy, the students should not only read information or posts made by others, but also observe the language use and question what behind the 
language use is. The questionnaire shows that most of the students just read the posts and regard social media as a means of sharing information.

Fairclough argues that critical literacy requires understanding literacy as a tool for social action, for example how language is organized to reproduce race, class, and gender roles (Dozier, Johnston, \& Rogers, 2006, p. 19). The previous social action is also provided in the questionnaire. In spite of their ignorance of social issues in society, 17 students already recognized this function of language. The notion of identity is observable in social media when people choose different patterns of language by different gender, for example.

As social action, language meaning is dependent to its context. Therefore, this is teachers' job to help students understand and critically interpret the information that comes via new technologies (Morrel, 2013, p. 302). The students can also observe language use in certain Facebook groups by paying attention to certain lexical choice found in the groups. The range of age of group members can be a delicate angle to observe different lexical choice made by the users. This issue is important to blow up in classroom discussion.

Critical literacy approaches view text-print and multimodal, paper based-and digital-and their codes and discourses as human technologies for representing and reshaping possible world (Luke \& Dooley, 2011, p. 856). Fauconnier and Turner (2002) mention that the twenty-first century is likely to be the century where meaning comes to the fore and perhaps even supercedes form as the major focus of interest (Lantolf, 2011, p. 303).

When digital natives make interactions in their virtual community, actually they have a chance to exercise their language use for certain purpose. For example, students can exchange information on recent issues in the society. The students can criticize videos shared in Facebook or Instagram. Students can criticize language use in videos or comments on the videos. From the comments, students can observe how people persuade others. They can also figure out how people's opinions are powerful so that the videos are shared by certain numbers of people. The previous example obviously displays that language use in social media is rich of sources. 
Critical literacy is an effective vehicle for teaching students how to analyse social issues and unequal power relationship. It can help students identify, reflect on and analyse underlying power relationships which are seldom apparent and rarely explored in texts or in the media (Roberge, 2013, p. 1). Critical literacy of social networks is designed to raise young people's ability to make critical and informed decisions of the communications they encounter both as text producer and text analyst (Douglas 2009). It is essential that young people are able to understand the complexity of the language rich world of social communication that they inhabit (Watson, 2012).

The students have potential to observe language use in Facebook and Instagram comments. It is in line with their responses in the questionnaire. The participants are interested in observing comments. It means that they are involved in seeing language as social action to process the information that they are inundanted via portal of information (Morrel, 2013, p. 302). In the digital era, youth people need to develop the skills to be able to create information that can be shared via websites, digital photographs and films, and online journal spaces like weblogs (blogs). Thus, developing critical media perspective can enlighten students to the potential that they have to shape the world they live in (Morrel, 2013, p. 302).

Barton \& Potts propose language as social practice approach which emphasizes how practices around texts and textual production are always for a purpose (2013, p. 816). To develop their critical literacy, teachers should equip students with the capacity to engage in practices. It requires a more sophisticated understanding of language than simply control of dominant resources (Barton \& Potts, 2013, p. 817).

Language learning is not only seen as developing students' ability to read and write. Meanwhile, as social practice, language learning shows how language learners observe and enter into communication online, how it augments their non-digital exchanges, and how such practices may or may not assist learners in achieving their larger social purposes (Barton \& Potts, 2013, p. 817).

To mediate the perspective, social networking closed with the digital natives can be utilized as a social learning resource and space for 
new literacy practices (Thurairaj, Hoon, Roy, \& Fong, 2015, p. 304). One of the possible chance provided for the students is like what was conducted by Lam (2000) who examined the use of pop music web page, instant messaging and emailing which provide the participants opportunities to design identities for themselves as language users (Jones, 2013, p. 846).

\section{Conclusion}

Social media have been closed to students' lives as they are the digital natives. The presence of Instagram and Facebook is proven to consume the students' daily life. The students' activities in social media which appeared the most in the questionnaire were reading posts, how people share information and comment it in the form of sentences. As second language learners, the participants should exercise their critical thinking by bringing what they observe in social media in their academic products, in this case is their research proposal. However, teachers are also responsible for attracting the students observe language use in social media. Therefore, critical literacy approach is suggested for the teachers.

\section{REFERENCES}

Barton, D., \& Potts, D. (2013, December). language Learning Online as Social Practice. TESOL Quarterly, 47(4), 815-820.

Basak, D., \& Yesilel, A. (2016). Technology-enhanced Language Learning for Digital Natives. Participatory Educational Research, 97-111.

Benini, S., \& Murray, L. (2013). Critically Evaluating Prensky in a Language Learning Context: The "Digital Natives/ Immigrants Debate" and Its Implications for CALL. EURO CALL Conference (pp. 25-30). Evora: Dublin/Voillans.

Brick, B. (2012). The Role of Social Networking Sites for Language Learning in UK Higher Education: The Views of Learners and Practitioners. International Journal of Computer Assisted Language Learning and Teaching (IJCALLT), 2(3), 35-53. 
Brown, J. D. (2011). Quantitative Research in Second Language Studies. In E. Hinkel, Handbook of Research in Second Language Teaching and Learning (pp. 190-206). New York: Routledge.

Buck, A. (2012). Examining Digital Literacy Pracitces on Social Network Sites. Research in Teaching of English, 47(1), 9-39.

Chen, H. (2013). Identity Practices of Multilingual Writers in Social Networking Spaces. Language Learning \& Technology, 17(2), 143-170.

Crystal, D. (2003). Language and the Internet. New York: Cambridge.

Digital Natives: How do They Learn? How to Teach Them? (2011, September). Policy Brief. UNESCO Institute for Information Technologies in Education.

Dornyei, Z. (2003). Questionnaires in Second Language Research. New Jersey: Lawrence Erlbaum Associates.

Dovchin, S. (2015). Language, multiple authenticities and social media: The online language practices of university students in Mongolia. Journal of Sociolinguistics, 19(4), 437-459.

Dozier, C., Johnston, P., \& Rogers, R. (2006). Critical Literacy Critical Thinking: Tools for Preparing Responsive Teachers. New York: Teachers College Press.

Faizi, R., Afia, A. E., \& Chibeb, R. (n.d.). Students' Perceptions on Social Media Use in Language Learning. International Conference ICT for Language Learning 6th Edition.

Gerger, E. (2014). Implications of Social Practice Theory for the Development of a Numeracy Programme for the Gusilay People Group in Senegal. ALM International Journal, 9(2), 85-96.

Jones, R. H. (2013). Research Methods in TESOL and Digital Literacies. TESOL Quarterly, 47(4), 843-848.

Krashen, S. D. (2009). Principles and Pratices in Second Language Acquisition. Oxford: Pergamon Press.

Kurata, N. (2011). Foreign Language Learning and Use. New York: Continuum International Publishing Group.

Lantolf, J. P. (2011). Integrating Sociocultural Theory and Cognitive Linguistics in the Second Language Classroom. In E. Hinkel, Handbook of Research in Second Language Teaching and Learning (pp. 303-318). New York: Routledge. 
Luke, A., \& Dooley, K. (2011). Critical Literacy and Second Language Learning. In E. Hinkel, Handbook of Research in Second Language Teaching and Learning (pp. 856-867). New York: Routledge.

Mackey, A., \& Gass, S. (2005). Second Language Research: Methodology and Design. New Jersey: Lawrence Erlbaum Associates.

Morrel, E. (2013). 21st Century Literacies, Critical Media Pedagogies, and Language Arts. The Reading Teacher, 66(4), 300-302.

Papen, U. (2005). Adult Literacy as Social Practice. London: Routledge.

Roberge, G. D. (2013, June). Promoting Critical Literacy accross the Curriculum and Fostering Safer Learning Environment. What Works? Research into Practice, pp. 1-4. Retrieved from www.edu.gov.on.ca/eng/literacynumeracy/inspire/research/ whatWorks.html

Smith, M. S. (1995). Second Language Learning: Theoretical Foundations. London: Longman Publishing .

Thurairaj, S., Hoon, E., Roy, S. S., \& Fong, P. W. (2015). Reflections of Students' Language Usage in Social Networking Sites: Making or Marring Academic English. The Electronic Journal of e-Learning, 13(4), 302-316.

Watson, P. (2012). Exploring Social Networking: Developing Critical Literacies. 